\title{
Modulation of spermatozoon acrosome reaction
}

\author{
Pilar Vigil ${ }^{1,2}$, Renán F. Orellana ${ }^{1}$, Manuel E. Cortés ${ }^{1,3}$ \\ 'Unidad de Reproducción y Desarrollo, Departamento de Fisiología, Facultad de Ciencias Biológicas, Pontificia Universidad Católica de Chile. Santiago, Chile. \\ ${ }^{2}$ Fundación Médica San Cristóbal. Santiago, Chile. \\ ${ }^{3}$ Programa de Postgrado, Departamento de Ciencias Animales, Facultad de Agronomía e Ingeniería Forestal, Pontificia Universidad Católica de Chile. Santiago, \\ Chile.
}

\begin{abstract}
Spermatozoon acrosome reaction is an exocytotic event of the utmost importance for the development of mammalian fertilisation. Current evidence shows that the triggering of the acrosome reaction (AR) could be regulated by the action of diverse compounds, namely, metabolites, neurotransmitters and hormones. The aim of the present review is to describe the modulating effects of several compounds that have been classified as inductors or inhibitors of acrosome reaction. Among AR inductors, it is necessary to mention progesterone, angiotensin II, atrial natriuretic peptide, cathecolamines, insulin, leptin, relaxin and other hormones. Regarding the inhibitors, oestradiol and epidermal growth factor are among the substances that retard AR. It is worth mentioning that gamma-aminobutyric acid, a neurotransmitter known to be an inhibitor in the central nervous system, has been shown to induce AR. The multiple hormones located in the fluids of the female reproductive tract are also likely to act as subtle regulators of AR, constituting a fundamental aspect for the development of successful fertilisation. Finally, it is necessary to emphasise that the study of regulation exerted by hormones and other compounds on AR is essential for further understanding of mammalian reproductive biology, especially spermatozoon physiology.
\end{abstract}

Key words: capacitation, gamma-aminobutyric acid, hormone modulation, sex steroids, spermatozoon acrosome reaction.

\section{INTRODUCTION}

The complex process of mammalian reproduction is based on a series of highly regulated and synchronised physiological events (Colombo, 2006; Familiari et al., 2006). The development of successful fertilisation depends on several aspects, among which it is worth mentioning physical (i.e., mechanical), biochemical, endocrine, behavioural and environmental factors. In mammals in which semen is deposited mainly in the vagina, e.g. humans, the existing spermatozoa have to ascend through the female reproductive tract (Vigil et al., 1994; Vigil et al., 1995). The latter can be considered a microenvironment that supplies the conditions needed to guarantee survival, capacitation and migration of spermatozoa required for subsequent fusion with the oocyte (Vigil et al., 1995). Fertilisation also depends on the morphological characteristics of the spermatozoon and the oocyte (Vigil, 1987; Familiari et al., 2006) and it is known that alterations in either gamete can have an impact on its attainment (Vigil et al., 1985; Vigil, 1987; Bustos-Obregón et al., 1995).

The spermatozoon is a haploid cell $(\mathrm{n})$ consisting of a head, neck, mid-piece and flagellum (Fawcett, 1975). The nucleus and the genetic material are located in the head, along with the acrosome (discussed in detail below). The flagellum is responsible for the motility of the spermatozoon due to the presence of structures such as the axoneme and a set of mitochondria that supply the energy required by the flagellar beating (Fawcett, 1975). Spermatozoa are produced in the testicles in a well-regulated process of differentiation known as spermatogenesis (von Kölliker, 1841), which involves all the phenomena through which a group of diploid cells (2n) become haploid spermatozoa.
As regards the acrosome -from Greek $\alpha \kappa \rho$ os (acros) meaning "highest", and $\sigma \omega \mu \alpha$ (soma) meaning "body"- this is an organelle, which by localisation and shape may resemble a hood, found in the apical region of the spermatozoon covering the anterior extremity of the nucleus. The acrosome has been described as a secretory vesicle, specifically as a modified lysosome (Moreno and Alvarado, 2006), and comprises varied enzymatic content including acrosin, acrogranin, hyaluronidase and other enzymes present in classic organelles, such as peroxisome, lysosome, and even in cytoplasm (McRorie and Williams, 1974; Moreno and Alvarado, 2006; Zhao et al., 2007). Each spermatozoon is endowed with an acrosome varying across species in shape and size, and its formation is a complex, highly regulated phenomenon as compared to the biogenesis of other organelles and secretory vesicles. In fact, many of its proteic components are synthesized in stages prior to the development of the male gamete (Moreno and Alvarado, 2006).

The objective of the present review is to describe the regulation exerted on spermatozoon acrosome reaction (AR), with special interest in the hormone modulation this process is subject to.

\section{WHAT IS AR?}

AR consists of the exocytosis of acrosomal content. This generally involves the fusion and fenestration of the spermatozoon plasma membrane with the outer acrosomal membrane. As a consequence of this process, small lipid cumuli are generated from both membranes, stabilising one another until they become independent units. The membranes that contain the enzymes of the acrosome lose continuity 
and stability leading to release of acrosome content to the external medium (Barros et al., 1967; Nagae et al., 1986; Llanos, 1989; Moreno and Alvarado, 2006). These series of events of membrane fusion have been studied mainly in the principal segment of the acrosome. However, AR has also been described at the equatorial segment level, in stages following exocytosis in the apical region (Nagae et al., 1986; Vigil, 1987; Vigil, 1989).

When AR has concluded, the spermatozoon has suffered various physiological changes that will later determine fertilisation, namely: a) acrosome enzyme release, which favours the passing of the spermatozoon through the zona pellucida; b) exposition of the inner acrosome membrane as a new cell surface domain (Nolan and Hammerstedt, 1997; Jungnickel et al., 2001); and c) in the case of the principal acrosome segment, acquisition of the fusogenic ability of the plasma membrane in the spermatozoon equatorial segment. These three events are important and necessary for fertilisation to occur. It has been described that the post-equatorial segment can also acquire this fusogenic capacity (Vigil, 1989; Jungnickel et al., 2001). Although the AR takes place first in the principal segment of the acrosome and later in the equatorial segment, our research establishes that the AR can occur asynchronically in the spermatozoon head, i.e., the fusion of the plasma membrane and the outer acrosome membrane can take place at different times and at different sites (Vigil, 1987; Vigil, 1989). In fact, it is possible to observe spermatozoa with a partial $\mathrm{AR}$ at the principal segment and at the equatorial segment of the acrosome. It has also been observed that, given a partial

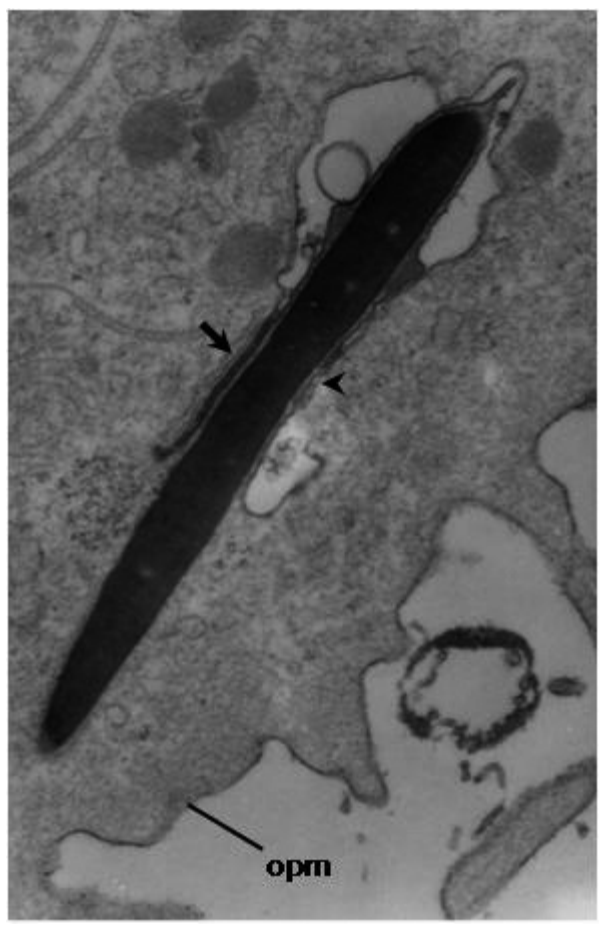

Figure 1: Transmission electron micrograph showing a hamster spermatozoon inside an immature hamster oocyte cytoplasm. The spermatozoon shows one side in which the acrosome equatorial segment is intact (arrow) and the other side in which the acrosome equatorial segment has reacted (arrow head). The oocyte plasma membrane is identified as opm (23000X).
$\mathrm{AR}$ of the equatorial segment, both the remaining plasma membrane of the unreacted part of the equatorial segment and the plasma membrane of the post-equatorial segment can acquire fusogenic capacity (Vigil, 1987; Vigil, 1989). This is supported by ultrastructural morphological evidence obtained after observing a spermatozoon in the oocyte cytoplasm with one side of the equatorial segment intact and the other side of the equatorial segment reacted (Figure 1). The ultrastructural evidence obtained by using an immature zona-free hamster oocyte shows that fusion between the oocyte plasma membrane and the spermatozoon plasma membrane across the equatorial and post-equatorial can occur (Vigil, 1987; Vigil, 1989).

The aforementioned physiological and morphological changes are fundamental during oocyte-spermatozoon interaction in the stages following the passage through the zona pellucida. The principal segment of the reacted spermatozoon has been found to possess domains able to interact with proteic components in the oocyte membrane that determine an initial anchoring between the two cells. These interactions later degrade, giving way to the fusion at the equatorial segment (Takano et al., 1993; Primakoff and Myles, 2002). The role of cyritestin, a protein found in the spermatozoon inner acrosome membrane (Linder et al., 1995) in the initial interaction between the oocyte and the principal spermatozoon segment is worth noting. It has also been described that the blocking of cyritestin receptors on the oocyte membrane interferes with spermatozoon binding (Yuan et al., 1997). As to the equatorial segment of the reacted spermatozoon, the existence of a group of lipids called seminolipids has been suggested (Gadella et al., 1995), which seem to be able to interact with SLIP, a protein of the oocyte membrane (Gadella et al., 1995). This could trigger a plasma membrane rearrangement favouring the fusion of both gametes. AR generates a remodelling of the spermatozoon cellular structure, enabling the fusion of its plasma membrane -over the equatorial or post-equatorial segment- with the oocyte plasma membrane (Vigil, 1987; Vigil, 1989; Familiari et al., 2006).

\section{REQUIREMENTS FOR THE OCURRENCE OF AR}

The timely occurrence and development of AR involves some prerequisites that depend mainly on changes at molecular level. Among these is capacitation, which is described below:

\section{Capacitation}

The physiological aspects of the reproductive process depend on a sequence of episodes that generate both the physical and chemical conditions that enable oocyte fertilisation (Barros et al., 1996; Colombo, 2006; Familiari et al., 2006). One of these events is spermatozoon capacitation, which encompasses a number of modifications that take place as sperm travel along the female reproductive tract and that involve a number of structural and biochemical changes in the spermatozoon (Barros, 1974; Go and Wolf, 1985; Hyne et al., 1985; Llanos, 1989; Fraser, 1995). These changes include an increase in plasma membrane fluidity, a decrease in the level of plasma cholesterol content (Go and Wolf, 1985; Cross, 1998), an increase in intracellular concentrations of calcium and cAMP (Yanagimachi and Usui, 1974; Yanagimachi, 1982; Visconti 
et al., 1990; Visconti et al., 1995; Visconti and Kopf, 1998), phosphorylation of tyrosine residues in proteins (Visconti et al., 1995; Leclerc et al., 1996), and a shift in the patterns of spermatozoon movement and motility (Yanagimachi, 1970). These are critical for AR since, as has been described, only capacitated spermatozoa can experience acrosome exocytosis (Bedford, 1983; Llanos, 1989; Yanagimachi, 1995; DeLamirande et al., 1997). The spermatozoon membrane possesses a variety of lipids whose localisation pattern allows for the occurrence of multiple cellular processes, such as protein location and changes in membrane fluidity. During capacitation, certain proteins in the uterine fluid, such as high density lipoprotein and albumin (Langlais and Roberts, 1985) enable extraction of cholesterol from the plasma membrane, leading to the distribution and re-localisation of these molecules in the spermatozoon (Fleming and Yanagimachi, 1981; Bearer and Friend, 1990). Capacitation affects the sensitivity of the male gamete to the diversity of ligands present in the female reproductive tract, especially in the uterus, oviduct and the oocyte, which trigger certain physiological changes in the spermatozoon, hence increasing the probability of oocyte fertilisation (see below). The relationship between gametes during fertilisation is also evidenced by the role exerted by ZP1, ZP2 and ZP3 (proteins present in the zona pellucida), which are capable of inducing AR through their interaction with a receptor located in the spermatozoon plasma membrane (Harkema et al., 1998; O'Toole et al., 2000).

\section{MODULATORS OF AR}

A variety of ligands have been reported to modulate AR exerting their effects by means of receptors at the level of the spermatozoon plasma membrane (Ohzu and Yanagimachi, 1982; Meizel, 1985; Hoshi et al., 1988; Morales et al., 1992; Llanos et al., 1993; Llanos et al., 1995; DelRío et al., 2007; Vigil et al., 2008). Some of these compounds are distributed in specific sectors of the female reproductive tract, probably exerting an in situ AR control (DelRío et al., 2007).

Among the ligands capable of affecting AR, we find the following hormones:

\section{Progesterone}

Progesterone is a steroid hormone that possesses a canonical signalling pathway consisting of the union with its nuclear receptors. This binding activates the transcription of several genes; hence, it is called the genomic signalling pathway. In the case of the human spermatozoon, this hormone participates in a range of processes such as: induction of AR (Roldan et al., 1994; Murase and Roldan, 1996; DeLamirande et al., 1997; Nolan and Hammerstedt, 1997) [in our studies, percentage of AR: $58.2 \pm 0.84$ in progesterone treatment vs. $29.0 \pm 0.71$ in control, $p<0.05$; (Vigil et al., 2008)], hyperactivation and increasing the percentage of spermatozoon penetration into hamster oocytes (Sueldo et al., 1993). Such effects are mediated by a non-genomic signalling pathway that operates through receptors present in the spermatozoon membrane (Shah et al., 2003). The action of progesterone is possible due to the increase in phosphorylation of cytoplasmic proteins, together with a transient rise in intracellular calcium concentration (Tesarik and Mendoza, 1993; Tesarik et al., 1993; Rathi et al., 2002). Cumulus oophorus secretes progesterone, thus there are important levels of this hormone present in the periovulatory follicular fluid (Morales et al., 1992). It has been shown that the decline of plasma membrane cholesterol during capacitation would determine the degree of response the human spermatozoon to progesterone (Cross and RazyFaulkner, 1997).

\section{Oestradiol}

Oestrogens are steroid hormones whose participation is fundamental in the female reproductive events, but they have also been reported to exert an important role in the male reproductive system (Hess et al., 1997). Although they classically act through the union with nuclear/cytoplasmic receptors, recent investigations show they could act in a faster/non-genomic via a variety of cell types, including the spermatozoon (Baldi et al., 1998; Luconi et al., 2004; Baldi et al., 2009). Oestradiol binds two subtypes of membrane receptors, $\alpha$ and $\beta$, both described in the human spermatozoon plasma membrane as presenting a different location (Solakidi et al., 2005). This generates an influx of calcium as mediator of the non-genomic effects (Luconi et al., 2004; Aquila et al., 2004). Oestradiol has been described as an AR inhibitor, with a lower observed percentage of human reacted spermatozoa as compared to those obtained in incubations with control (without oestradiol) spermatozoa preparations [percentage of AR: $29.4 \pm 0.55$ oestradiol treatment vs. $32.6 \pm 0.55$ in control, $p<0.05$ (Vigil et al., 2008)]. In the physiological context of fertilisation, the spermatozoa have to migrate through the cervical mucus (Vigil et al., 1995). This biological fluid, found in some mammals, such as rabbits, ruminants and primates, possesses rheological properties subject to endocrine regulation, and these characteristics change in physiological and pathophysiological conditions (Vigil et al., 1991; Morales et al., 1993; Vigil et al., 1995; Ceric et al., 2005; Vigil et al., 2009a). After passing through the cervical mucus and endometrial cavity, the spermatozoa in the Fallopian tube come in contact with the follicular fluid. The high concentrations of oestradiol present in the cervical mucus during the female fertile period could exert an inhibitory role on $\mathrm{AR}$, preventing the premature occurrence of the latter during the passage of spermatozoa along the uterine cervix. Progesterone, which has been found in follicular fluid during the periovulatory period (Morales et al., 1992), could play a stimulating effect on AR when spermatozoa are in the proximity of the oocyte. This suggests that the variable concentrations of steroid hormones during the female reproductive cycle could have a crucial role in spermatozoon physiology (Vigil et al., 2009c).

\section{Angiotensin II}

This hormone possesses a wide range of physiological functions, among which arterial blood pressure control and plasma volume regulation are worth mentioning since they currently constitute an important therapeutic target in cardiovascular pathologies. These effects are produced by the union of Angiotensin II to surface receptors, among which two types have been described, $\mathrm{AT}_{1}$ and $\mathrm{AT}_{2}$ (Griendling et al., 1996). Some studies have shown that, in bovines and humans, this hormone can act as an AR inductor by binding to its $\mathrm{AT}_{1}$ receptor (Gur et al., 1998; Köhn et al., 1998). This AR modulation is dependent on extracellular calcium 
concentration and can be inhibited by the administration of losartan, a selective $\mathrm{AT}_{1}$ receptor inhibitor (Vinson et al., 1995; Gur et al., 1998). The $\mathrm{AT}_{1}$ receptor is found mainly on the tail of the spermatozoon. However, in capacitated bovine spermatozoa it is most commonly present on the head (Gur et al., 1998). A study in equines Sabeur et al. (2000) found that the addition of a dose of angiotensin II ranging from 1 to 100 $\mathrm{nmol} / \mathrm{L}$ to capacitated spermatozoa during $20 \mathrm{~min}$ resulted in a significant increase in live reacted acrosome spermatozoa (percentage of AR: 24.9 to 22.6 in treated cells vs. 9.8 in control, $p<0.05)$. Such effect could be mediated by the above mentioned $\mathrm{AT}_{1}$ receptor (Sabeur et al., 2000). Angiotensin II levels have been reported in follicular fluid (Heimler et al., 1995), a finding that leads to the hypothesis that this hormone can have a physiological role in in vivo induction of $\mathrm{AR}$, but the underlying mechanisms of the process have not as yet been clearly explained.

\section{Atrial natriuretic peptide}

Atrial natriuretic peptide (ANP), also known as atrial natriuretic hormone, is a powerful vasodilator peptide produced by heart muscle cells (Potter et al., 2009). ANP has been found in mammalian reproductive tissue, e.g. oviducts (Zhang et al., 2006), as well as in ovarian follicular fluid (Anderson et al., 1994). Evidence suggests that the spermatozoon possesses ANP receptors (Rotem et al., 1998; Zhang et al., 2006). To date, it has been possible to determine that ANP induces AR in human (Anderson et al., 1994; Anderson et al., 1995; Rotem et al., 1998), bovine (Zamir et al., 1995), giant panda (Zhang et al., 2005) and pig spermatozoa (Zhang et al., 2006). The latter evidence suggests that ANP may be involved in the regulation of the acrosome exocytosis and the fertilising ability of mammalian spermatozoa, and it has been suggested that the cGMP-dependent protein kinase pathway possibly participates in this process (Zhang et al., 2006).

\section{Catecholamines}

Adrenalin and noradrenalin are catecholamine hormones widely known for their effect on the autonomic nervous system. In spite of this, high concentration levels of these hormones have been determined in the oviductal fluid of mammals (Way et al., 2001). Noradrenalin is described as an AR inducing hormone in bovine spermatozoa, showing an optimal concentration for maximal response and generating higher rates of capacitation, as compared to control incubations (Way and Killian, 2002). Similar effects have also been reported for the addition of adrenalin. Nevertheless, noradrenalin evidences a more relevant increase, both in the percentage of reacted bull spermatozoa and the observed capacitation rates (Way and Killian, 2002). Finally, the catecholamine hormone dopamine has no effect whatsoever on the characteristics of the bull spermatozoa under study (Way and Killian, 2002).

\section{Epidermal growth factor}

Epidermal growth factor (EGF), also known as epidermal growth hormone, is a 53 amino acid polypeptide known to be an inductor of cellular growth, proliferation and differentiation in various tissues. EGF has been reported to exert a role in cellular proliferation in the human testicles, favouring mice spermatozoa production (Tsutsumi et al., 1986). EGF receptors have been found in the spermatozoa of different mammals, including humans (Naz and Ahmed, 1992). These receptors correspond to the classic $170 \mathrm{kDa}$ protein in somatic cells (Lax et al., 1994). EGF has been described as an AR inhibitor in humans, causing a dose-dependent decrease in the percentage of reacted spermatozoa (percentage of AR: $51.62 \pm 4.23$ EGF treatment vs. $67.02 \pm 4.36$ in control; $p<0.05$ ). This could also lead to a reduction in the rate of penetrated oocytes and a decline in the spermatozoon kinetic variables such as velocity and flagellar beat frequency (Naz and Kaplan, 1993).

\section{Insulin}

Insulin, a peptide hormone produced in the pancreas by $\beta$ cells of the islets of Langerhans, has well-known functions in glycaemic homeostasis, also participating in processes of differentiation, growth, development and cell metabolism (Brüning et al., 2000; Saltiel and Kahn, 2001). Several studies have also linked this hormone, as well as its associated signalling pathways, to the regulation of multiple functions implied in reproduction (Ali et al., 1993; Brüning et al., 2000; Lampiao et al., 2009).

The role exerted by insulin in human spermatozoon biology has been evidenced in research on men suffering from diabetes mellitus type 2, whose spermatozoa possess severe structural and morphological defects (Bacetti et al., 2002), reduced motility and lower ability to penetrate hamster oocytes (Shrivastav et al., 1989). A recent study on the in vitro effects of this hormone on diverse human spermatozoon variables has determined that treating spermatozoa with insulin significantly increases spontaneous AR, as compared to control (35.33 $\pm 1.73 \%$ versus $14.56 \pm 0.64 \%$, respectively, $p$ $<0.05$ ), and that this administration also leads to an increase in spermatozoon total and progressive motility (Lampiao and du Plessis, 2008). It was also found that inhibiting phosphatidylinositol 3-kinase -an intracellular insulin effectorby means of wortmannin caused a decrease in the observed percentage of AR in insulin treated spermatozoa (Lampiao and $\mathrm{du}$ Plessis, 2008). The aforementioned evidence, and the fact that insulin is present in ejaculated spermatozoa (Aquila et al., 2005a), make it possible to attribute eventual functions on spermatozoon physiology to this hormone.

Leptin

Leptin is a peptide hormone with a molecular mass of approximately $16 \mathrm{kDa}$ produced by the gene $L E P$, which was initially reported as the $o b$ gene in mice. It is constituted by 166 amino acids, contains a disulphide bridge needed for its biological activity and is produced by adipocytes. This hormone exerts a crucial function in glucose and lipid homeostasis, especially in body mass control through the regulation of food intake and thermogenesis (Farooqi and O'Rahilly, 2009). Current evidence suggests that leptin is involved in the regulation of several processes related to mammalian reproduction (Moschos et al., 2002; Lampiao et al., 2009). The determination by Aquila et al. (2005b) that human ejaculated spermatozoa contain this hormone has led to the questioning of the possible role of leptin on the spermatozoon (Andò and Aquila, 2005). In a study by Lampiao and du Plessis 
(2008) designed to determine the in vitro effects of leptin on some variables of the human spermatozoon, this hormone in particular has been shown to affect acrosome exocytosis. In fact, treating spermatozoa with leptin significantly increases spontaneous AR as compared to control (36.56 $\pm 1.93 \%$ vs. $14.56 \pm 0.64 \%$, respectively, $p<0.05$ ), and this administration also leads to an increase in spermatozoa motility (Lampiao and du Plessis, 2008). However, the molecular mechanisms underlying the aforementioned results for this hormone have not as yet been elucidated and remain to be determined.

Prolactin

Prolactin (PRL), a hormone synthesised and released by the adenohypophysis lactotroph cells, is responsible for the stimulation and production of milk in the mammary glands, and for exerting other multiple functions related to mammalian reproduction (Smith, 1980). Considering that PRL is present throughout the female reproductive tract (Mori et al., 1988), that its receptor has been identified in mammalian spermatozoa (Hashimoto et al., 1988), and that this hormone shortens the optimal preincubation period for mice spermatozoa to acquire capacitation (Fukuda et al., 1989), it is likely that PRL could be exerting some effect on AR. Stovall and Shabanowitz (1991) studied the effects of PRL on spermatozoon capacitation and its ability to induce AR, and found that, apparently, this hormone has no significant effect on capacitation and AR of the human spermatozoon (Stovall and Shabanowitz, 1991). However, further studies are required in order to assess the role of PRL in the acrosome exocytosis.

\section{Relaxin}

Relaxin, a peptide hormone with a molecular mass of approximately $6000 \mathrm{Da}$, has been described as having important roles in mammalian pregnancy, being involved in events such as relaxation and softening of the uterus, as well as in pubic symphysis during childbirth. This hormone has been found in human seminal plasma (Essig et al., 1982; Lessing et al., 1986) and it has been found that it exerts physiological effects on spermatozoon motility in certain species of domestic animals, such as bulls (Kohsaka et al., 2003). Miah et al. (2006) showed that boar spermatozoa incubation with relaxin significantly stimulates motility, the percentage of AR and glucose use. A more recent work found that the addition of this hormone leads to an increase of these variables in bovine spermatozoa (Miah et al., 2007). These results suggest the physiological significance of using relaxin on spermatozoon variables in mammals, especially as regards AR induction.

\section{Gamma-aminobutyric acid}

Even though gamma-aminobutyric acid (GABA) is not in itself a hormone, it shows interesting effects on AR. It is known that GABA is an inhibitory neurotransmitter in the central nervous system, and participates in most of the inhibitory synapses that enable neuronal activity. In spite of this, this compound has also been also described in a variety of cellular events in non-neuronal peripheral tissues, which has led some authors to suggest it is a trophic factor, or even a hormone (Ong and Kerr, 1990; Gladkevich et al., 2006). GABA is also present in tissues such as the human uterus, oviducts and ovaries (Erdö et al., 1989), as well as in certain fluids, such as human seminal plasma (Leader et al., 1992). Regarding AR, GABA has also been described to be a dose-dependent inductor of this process (Shi et al., 1997). Its effects appear to be mediated by receptors located in the spermatozoon membrane, whose activation implies an increase in cytoplasmic calcium concentration and subsequent acrosome exocytosis (Aanesen et al., 1995). In relation to the latter, two types of GABA receptors have been described, types $\mathrm{A}$ and $\mathrm{B}$, both present in the spermatozoon (Aanesen et al., 1995). Studies performed on ligands specific for each receptor have made it possible to conclude that the GABA (A) receptor is the most efficient inductor of AR (Calogero et al., 1999; Hu et al., 2002).

Both GABA and progesterone seem to exert similar effects on processes associated to spermatozoon physiology, such as AR, capacitation and hyperactivation (Calogero et al., 1996; Shi et al., 1997; Calogero et al., 1999). It has also been shown that the GABA receptor in the spermatozoon can be activated by progesterone and some of its metabolites; this interaction results in an increased chloride flux essential to AR initiation (Wistrom and Meizel, 1993). Our research group has recently reported that both GABA and progesterone induced human AR can be regulated by the effects of oestradiol, formerly described as an AR inhibitor [percentage of AR: $58.2 \pm 0.84$ progesterone treatment vs. $30.0 \pm 0.84$ progesterone + oestradiol treatment; $33 \pm 1.16$ GABA vs. $17 \pm 1.47$ GABA + oestradiol treatment, $p$ $<0.05$ (Vigil et al., 2008; Vigil et al., 2009b; Vigil et al., 2009c)]. Thus, we have suggested a possible hormone interaction, through non-genomic pathways, among progesterone, GABA and oestradiol in physiological processes such as AR (Vigil et al., 2009c). This interaction could also be present in somatic cells.

The compounds that exert a role on AR modulation are shown in Figure 2.

\section{CONCLUDING REMARKS}

Spermatozoon AR is affected by a series of chemical substances and metabolites, as well as by the action of a number of hormones. The meaning and biological relevance of the effects on AR attributed to such hormones are far from being elucidated and thoroughly understood, although this topic is today subject of active research (Meizel, 2004; Andò and Aquila, 2005; Lampiao and du Plessis, 2008; Vigil et al., 2008; Vigil et al., 2009c; Baldi et al., 2009; and other groups). This review was focused upon the hormones that we recognise as the most important modulators of AR. Nevertheless, there may be other hormones acting as regulators of the AR that are yet to be recognised. Considering the current evidence and what has been mentioned, it is probable that the changes in hormonal levels that occur in vivo in the reproductive tract of the female of each species during the reproductive cycle subtly regulate the $A R$, retarding the onset or favouring its timely occurrence. As regards this delicate hormonal modulation that AR could be subject to, it is necessary to mention again the case of steroid hormones, about which more information is available: in the cervix, the oestradiol present in the periovulatory cervical mucus could be exerting the role of AR inhibitor since its onset in such regions of the female reproductive tract would not make fertilisation possible (Ceric et al., 2005; Vigil et al., 2008; Vigil et al., 2009b). On the contrary, in the distal third of the Fallopian tube, there are high levels of progesterone coming 
from the follicular fluid, which could promote AR precisely when the spermatozoon and the oocyte are close to encounter, favouring successful fertilisation (Morales et al., 1992; Vigil et al., 2008; Vigil et al., 2009c). The latter constitutes a feasible and coherent explanation in the context of the reproductive process, and possibly other hormones and metabolites of physiological interest could also be participating in this subtle AR regulation, together or simultaneously with steroid hormones.

The variations in the concentrations of cytoplasmic calcium, cAMP and the phosphorylation of proteic residues are currently some of the non-genomic effectors of steroid hormones. Such signalling components have been described both in somatic cells and in spermatozoa (Baldi et al., 2009). The inactivation of the nucleus, and thus the absence of transcription, confers the male gamete an advantage as a study model for the non-genomic action of steroid hormones. For this reason, the knowledge obtained from experiments on spermatozoa could explain the non-genomic response of somatic cells as regards these and other types of hormones.

In keeping with current research on steroid hormones and $A R$, further studies should focus on determining the hormones that, in fact, exert a significant effect on AR modulation, as well as the molecular mechanisms of the signal transduction pathways that underlie this regulation. This will make it possible to propose a future physiological explanation to integrate the effects that the compounds mentioned above have on AR. This information would certainly help elucidate other even more relevant questions, namely: what is the biological relevance of hormone modulation on AR? And what is the significance of such modulation for the reproductive events posterior to acrosome exocytosis? Our research group is currently aiming to find the answers to these questions.

\section{ACKNOWLEDGEMENTS}

M. E. Cortés thanks the Comisión Nacional de Investigación Científica y Tecnológica (CONICYT, Chile) and Beca Matrícula Facultades (FAIF, Pontificia Universidad Católica de Chile) for the scholarships granted for doctoral studies. Finally, we dedicate this review to the memory of our teacher, colleague, and friend Professor Dr. Claudio Barros (1936-2008), a renowned biologist who devoted his career to reproductive biology, especially to the study of acrosome reaction.

\section{REFERENCES}

AANESEN A, FRIED G, ANDERSSON E, GOTTLIEB C (1995) Evidence for gamma-aminobutyric acid specific binding sites on human spermatozoa. Hum Reprod 10: 1885-1890.

ALI ST, SHAIKH RN, SIDDIQI NA, SIDDIQI PQ (1993) Semen analysis in insulin-dependent/non-insulin-dependent diabetic men with/without neuropathy. Arch Androl 30: 47-54.

ANDERSON RA, FEATHERGILL KA, DRISDEL RC, RAWLINS RG, MACK SR, ZANEVELD LJ (1994) Atrial natriuretic peptide (ANP) as a stimulus of the human acrosome reaction and a component of ovarian follicular fluid: correlation of follicular ANP content with in vitro fertilization outcome. J Androl 15: 61-70.

ANDERSON RA, FEATHERGILL KA, RAWLINS RG, MACK SR, ZANEVELD LJ (1995) Atrial natriuretic peptide: a chemoattractant of human spermatozoa by a guanylate cyclase-dependent pathway. Mol Reprod Dev 40: 371-378.

ANDOे S, AQUILA S (2005) Arguments raised by the recent discovery that insulin and leptin are expressed in and secreted by human ejaculated spermatozoa. Mol Cell Endocrinol 245: 1-6.

AQUILA S, SISCI D, GENTILE M, MIDDEA E, CATALANO S, CARPINO A, RAGO V, ANDÒ S (2004) Estrogen receptor (ER) $\alpha$ and ER $\beta$ are both expressed in human ejaculated spermatozoa: evidence of their direct interaction with phosphatidylinositol-3-OH kinase/Akt pathway. J Clin Endocrinol Metab 89: 1443-1451.

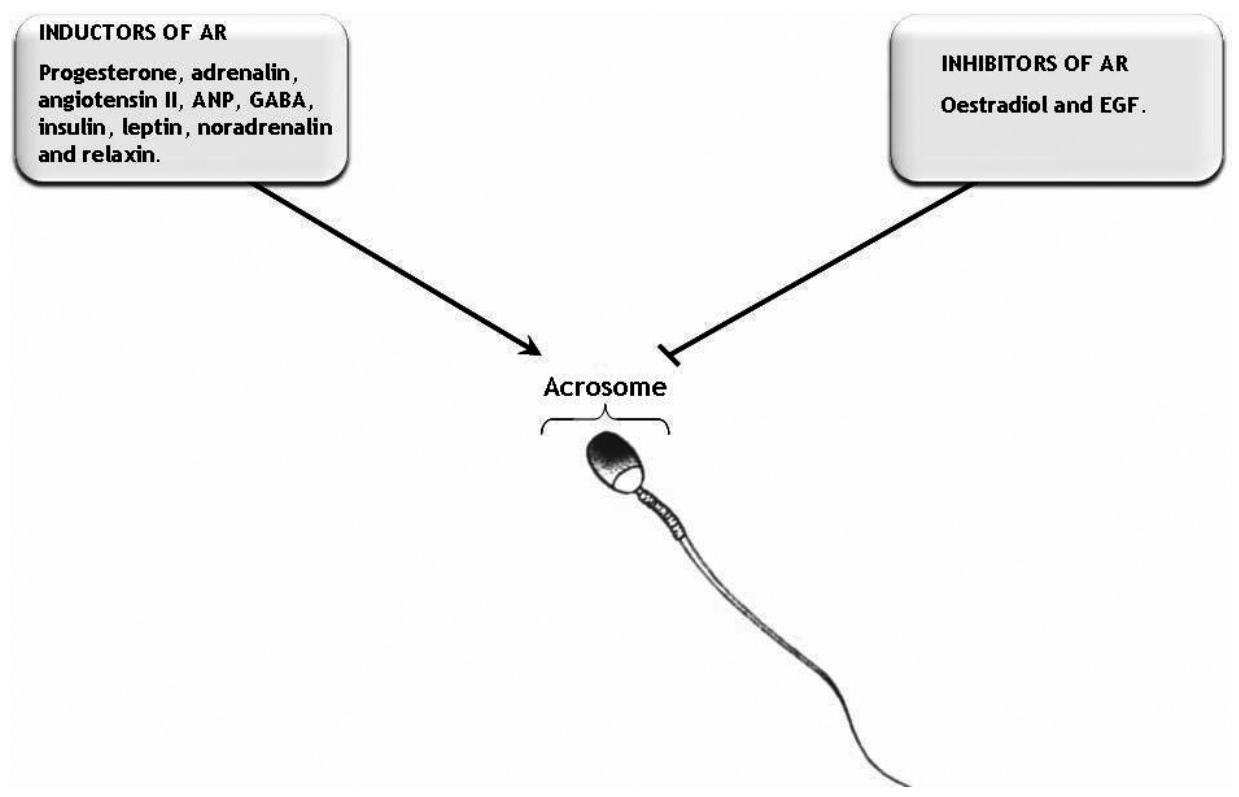

Figure 2: Compounds that exert a role on AR modulation. AR: acrosome reaction; ANP: atrial natriuretic peptide; GABA: gamma-aminobutyric acid; EGF: epidermal growth factor. 
AQUILA S, GENTILE M, MIDDEA E, CATALANO S, ANDÒ S (2005a) Autocrine regulation of insulin secretion in human ejaculated spermatozoa. Endocrinology 146: 552-557.

AQUILA S, GENTILE M, MIDDEA E, CATALANO S, MORELLI C, PEZZI V, ANDÒ S (2005b) Leptin secretion by human ejaculated spermatozoa. J Clin Endocrinol Metab 90: 4753-4761.

BACCETTI B, LAMARCA A, PIOMBONI P, CAPITANI S, BRUNI E, PETRAGLIA F, DELEO V (2002) Insulin-dependent diabetes in men is associated with hypothalamo-pituitary derangement and with impairment in semen quality. Hum Reprod 17: 2673-2677.

BALDI E, LUCONI M, BONACCORSI L, FORTI G (1998) Nongenomic effects of progesterone on spermatozoa: mechanisms of signal transduction and clinical implications. Front Biosci 3: D1051-D1059.

BALDI E, LUCONI M, MURATORI M, MARCHIANI S, TAMBURRINO L, FORTI G (2009) Nongenomic activation of spermatozoa by steroid hormones: facts and fictions. Mol Cell Endocrinol 308: 39-46.

BARROS C, BEDFORD JM, FRANKLIN LE, AUSTIN CR (1967) Membrane vesiculation as a feature of the mammalian acrosome. J Cell Biol 34: C1-C5

BARROS C (1974) Capacitation of mammalian spermatozoa. Basic Life Sci 4: 3-24.

BARROS C, CROSBY JA, MORENO RD (1996) Early steps of sperm-egg interactions during mammalian fertilization. Cell Biol Int 20: 33-39.

BEARER EL, FRIEND DS (1990) Morphology of mammalian sperm membranes during differentiation, maturation, and capacitation. J Electron Microsc Tech 16: 281-297.

BEDFORD JM (1983) Significance of the need for sperm capacitation before fertilization in eutherian mammals. Biol Reprod 28: 108-120.

BRÜNING JC, GAUTAM D, BURKS DJ, GILLETTE J, SCHUBERT M, ORBAN PC, KLEIN R, KRONE W, MÜLLER-WIELAND D, KAHN CR (2000) Role of brain insulin receptor in control of body weight and reproduction. Science 289: 2122-2125.

BUSTOS-OBREGÓN E, VIGIL P, MORALES P (1995) Infertilidad masculina. In: PÉREZ SÁNCHEZ A (ed) Ginecología. Santiago: Publicaciones Técnicas Mediterráneo. pp: 398-416.

CALOGERO AE, HALL J, FISHEL S, GREEN S, HUNTER A, DAGATA R (1996) Effects of gamma-aminobutyric acid on human sperm motility and hyperactivation. Mol Hum Reprod 2: 733-738.

CALOGERO A, BURRILLO M, FERRARA E, HALL J, FISHEL S, DAGATA R (1999) Gamma-amino butyric acid (GABA) A and B receptors mediate the stimulatory effects of GABA on the human sperm acrosome reaction: interaction with progesterone. Fertil Steril 71: 930-936.

CERIC F, SILVA D, VIGIL P (2005) Ultrastructure of the human periovulatory cervical mucus. J Electron Microsc 54: 479-484.

COLOMBO R (2006) The process of fertilization and its stages. From parental gametes to a developing one-cell embryo. In: SGRECCIA E, LAFFITTE J (eds) Proceedings of the XII Assembly of the Pontifical Academy for Life. Vatican City: Libreria Editrice Vaticana. pp: 37-127.

CROSS NL, RAZY-FAULKNER P (1997) Control of human sperm intracellular $\mathrm{pH}$ by cholesterol and its relationship to the response of the acrosome to progesterone. Biol Reprod 56: 1169-1174.

CROSS NL (1998) Role of cholesterol in sperm capacitation. Biol Reprod 59: 7-11.

DELAMIRANDE E, LECLERC P, GAGNON C (1997) Capacitation as a regulatory event that primes spermatozoa for the acrosome reaction and fertilization. Mol Hum Reprod 3: 175-194.

DELRÍO MJ, GODOY A, TORO A, ORELLANA R, CORTÉS ME, MORENO RD, VIGIL P (2007) La reacción acrosómica del espermatozoide: avances recientes. Rev Int Androl 5: 368-373.

ERDÖ SL, VILLÁNYI P, LÁSZLÓ A (1989) Gestational changes of GABA levels and GABA binding in the human uterus. Life Sci 44: 2009-2014.

ESSIG M, SCHOENFELD C, D'ELETTO RT, AMELAR R, STEINETZ BG, OBYRNE EM, WEISS G (1982) Relaxin in human seminal plasma. Ann N Y Acad Sci 380: 224-230.

FAMILIARI G, HEYN R, RELUCENTI M, NOTTOLA SA, SATHANANTHAN AH (2006) Ultrastructural dynamics of human reproduction, from ovulation to fertilization and early embryo development. Int Rev Cytol 249: 53-141.

FAROOQI IS, ORAHILLY S (2009) Leptin: a pivotal regulator of human energy homeostasis. Am J Clin Nutr 89: 980S-984S

FAWCETT DW (1975) The mammalian spermatozoa. Dev Biol 44: 394-436.

FLEMING AD, YANAGIMACHI R (1981) Effects on the acrosome reaction and fertilizing capacity of guinea pig spermatozoa with special reference to the possible involvement of lysophospholipids in the acrosome reaction. Gamete Res 4: 253-273.

FRASER LR (1995) Mechanisms regulating capacitation and the acrosome reaction. In: FÉNICHEL P, PARINAUD J (eds) Human sperm acrosome reaction. Proceedings of the international symposium on "Human sperm acrosome reaction, physiological and pharmacological induction and transduction pathways". Montrouge: John Libbey Eurotext Ltd. pp: 17-33.

FUKUDA A, MORI C, HASHIMOTO H, NODA Y, MORI T, HOSHINO K (1989) Effects of prolactin during preincubation of mouse spermatozoa on fertilizing capacity in vitro. J In Vitro Fert Embryo Transf 6: 92-97.

GADELLA BM, LOPES-CARDOZO M, VANGOLDE LMG, COLENBRANDER B, GADELLA TWJ (1995) Glycolipid migration from the apical to the equatorial subdomains of the sperm head plasma membrane precedes the acrosome reaction. Evidence for a primary capacitation event in boar spermatozoa. J Cell Sci 108: 935-946.

GLADKEVICH A, KORF J, HAKOBYAN VP, MELKONYAN KV (2006) The peripheral GABAergic system as a target in endocrine disorders. Auton Neurosci 124: 1-8.

GO KJ, WOLF DP (1985) Albumin-mediated changes in sperm sterol content during capacitation. Biol Reprod 32: 145-153.

GRIENDLING KK, LASSÈGUE B, ALEXANDER RW (1996) Angiotensin receptors and their therapeutic implications. Annu Rev Pharmacol Toxicol 36: 281-306.

GUR Y, BREIBART H, LAX Y, RUBINSTEIN S, ZAMIR N (1998) Angiotensin II induces acrosomal exocytosis in bovine spermatozoa. Am J Physiol Endocrinol Metab 275: 87-93.

HARKEMA W, HARRISON RAP, MILLER NGA, TOPPER EK, WOELDERS H (1998) Enhanced binding of zona pellucida proteins to the acrosomal region of intact boar spermatozoa in response to fertilizing conditions: A flow cytometric study. Biol Reprod 58: 421-430.

HASHIMOTO H, IZUMI S, MORI C, NAKANE P, HOSHINO K (1988) Immunohistochemical observation of prolactin receptor in rat epididymal spermatozoa by backscattered electron imaging. In: HOSHINO K (ed) Prolactin gene family and its receptors. Molecular biology to clinical problems. Amsterdam: Elsevier Science Ltd. pp: 341344.

HEIMLER I, RAWLINS R G, BINOR Z, AIMAN J, RAFF H, HUTZ RJ (1995) Elevated follicular fluid angiotensin II and pregnancy outcome. Fertil Steril 63: 528-534.

HESS RA, BUNICK D, LEE KH, BAHR J, TAYLOR JA, KORACH KS, LUBAHN DB (1997) A role of oestrogen on male reproductive system. Nature 390: 509-512

HOSHI M, MATSUI T, NISHIYAMA I, AMANO T, OKITA Y (1988) Physiological inducers of the acrosome reaction. Cell Differ Dev 25: 19-24.

HU JH, HE XB, WU Q, YAN YC, KOIDE SS (2002) Biphasic effect of GABA on rat sperm acrosome reaction: involvement of $\mathrm{GABA}(\mathrm{A})$ and $\mathrm{GABA}(\mathrm{B})$ receptors. Arch Androl 48: 369-378.

HYNE RV, EDWARDS KP, LOPATA A, SMITH JD (1985) Changes in guinea pig sperm intracellular sodium and potassium content during capacitation and treatment with monovalent ionophores. Gamete Res 12: $65-73$.

JUNGNICKEL MK, MARRERO H, BIRNBAUMER L, LÉMOS JR, FLORMAN $\mathrm{HM}$ (2001) Trp2 regulates entry of $\mathrm{Ca}^{2+}$ into mouse sperm triggered by egg ZP3. Nat Cell Biol 3: 499-502.

KÖHN FM, MÜLLER C, DRESCHER D, NEUKAMM C, ELMULLA KF, HENKEL R, HÄGELE W, HINSCH E, HABENICHT UF, SCHILL WB (1998) Effect of angiotensin converting enzyme (ACE) and angiotensins on human sperm functions. Andrologia 30: 207-215.

KOHSAKA T, HAMANO $K$, SASADA H, WATANABE $S$, OGINE T, SUZUKI E, NISHIDA S, TAKAHARA H, SATO E (2003) Seminal immunoreactive relaxin in domestic animals and its relationship to sperm motility as a possible index for predicting the fertilizing ability of sires. Int J Androl 26: $115-120$

LAMPIAO L, AGARWAL A, DUPLESSIS SS (2009) The role of insulin and leptin in male reproduction. Arch Med Sci 5: S48-S54.

LAMPIAO F, DUPLESSIS SS (2008) Insulin and leptin enhance human sperm motility, acrosome reaction and nitric oxide production. Asian J Androl 10: 799-807.

LANGLAIS J, ROBERTS KD (1985) A molecular membrane model of sperm capacitation and the acrosome reaction of mammalian spermatozoa. Gamete Res 12: 183-224.

LAX Y, RUBINSTEIN S, BREITBART H (1994) Epidermal growth factor induces acrosomal exocytosis in bovine sperm. FEBS Letters 339: 234-238

LEADER A, MINUK GY, MORTIMER D (1992) Seminal plasma gammaaminobutyric acid (GABA) levels in normospermic men. Clin Invest Med 15: 346-348.

LECLERC P, DELAMIRANDE E, GAGNON C (1996) Cyclic adenosine $3^{\prime}, 5^{\prime}$ monophosphate dependent regulation of protein tyrosine phosphorylation in relation to human sperm capacitation and motility. Biol Reprod 55: 684-692. 
LESSING JB, BRENNER SH, COLON JM, GINSBURG FW, SCHOENFELD C, GOLDSMITH LT, SAROSI P, AMELAR RD, DUBIN L, WEISS G (1986) Effect of relaxin on human spermatozoa. J Reprod Med 31: 304-309.

LINDER B, BAMMER S, HEINLEIN UA (1995) Delayed translation and posttranslational processing of cyritestin, an integral transmembrane protein of the mouse acrosome. Exp Cell Res 221: 66-72.

LLANOS MN (1989) La reacción acrosómica en espermatozoide de mamífero. Aspectos bioquímicos. Arch Biol Med Exp 22: 25-36.

LLANOS M, VIGIL P, SALGADO AM, MORALES P (1993) Inhibition of the acrosome reaction by trypsin inhibitors and prevention of penetration of spermatozoa through the human zona pellucida. J Reprod Fertil 97: 173-178.

LLANOS MN, MORALES P, SALGADO AM, VIGIL P (1995) Effect of lysophospholipids on the human sperm acrosome reaction. In: Human sperm acrosome reaction. Proceedings of the international symposium on "Human sperm acrosome reaction, physiological and pharmacological induction and transduction pathways". Montrouge: John Libbey Eurotext Ltd. pp: 410-411.

LUCONI M, FRANCAVILLA F, PORAZZI I, MACEROLA B, FORTI G, BALDI E (2004) Human spermatozoa as a model for studying membrane receptors mediating rapid nongenomic effects of progesterone and estrogens. Steroids 69: 553-539.

MCRORIE RA, WILLIAMS WL (1974) Biochemistry of mammalian fertilization. Ann Rev Biochem 43: 777-803.

MEIZEL S (1985) Molecules that initiate or help stimulate the acrosome reaction by their interaction with the mammalian sperm surface. Am J Anat 174: 285-302.

MEIZEL S (2004) The sperm, a neuron with a tail: 'neuronal' receptors in mammalian sperm. Biol Rev Camb Philos Soc 79: 713-732.

MIAH AG, TAREQ KMA, HAMANO K, KOHSAKA T, TSUJII H (2006) Effect of relaxin on acrosome reaction and utilization of glucose in boar spermatozoa. J Reprod Dev 52: 773-779.

MIAH AG, SALMA U, TAREQ K, KOHSAKA T, TSUJII H (2007) Effect of relaxin on the motility, acrosome reaction and utilization of glucose of fresh and frozen-thawed bovine spermatozoa. Animal Sci J 78: 495-562.

MORALES P, LLANOS M, GUTIÉRREZ G, KOHEN P, VIGIL P, VANTMAN D (1992) The acrosome reaction inducing activity of individual human follicular fluid samples is highly variable and is related to the steroid content. Hum Reprod 7: 646-651.

MORALES P, ROCO M, VIGIL P (1993) Human cervical mucus: relationship between biochemical characteristics and ability to allow migration of spermatozoa. Hum Reprod 8: 78-83.

MORENO RD, ALVARADO CP (2006) The mammalian acrosome as a secretory lysosome: new and old evidence. Mol Reprod Dev 73: 14301434.

MORI C, HARIGAYA T, HOSHINO K, FUKUDA A (1988) Effects of mouse prolactin on acrosomal reaction of spermatozoa in mice in vitro. In: HOSHINO K (ed) Prolactin gene family and its receptors. Molecular biology to clinical problems. Amsterdam: Elsevier Science Ltd. pp: 183186.

MOSCHOS S, CHAN JL, MANTZOROS CS (2002) Leptin and reproduction: a review. Fertil Steril 77: 433-444.

MURASE T, ROLDAN ER (1996) Progesterone and the zona pellucida activate different transducing pathways in the sequence of events leading to diacylglycerol generation during mouse sperm acrosomal exocytosis. Biochem J 320: 1017-1023.

NAGAE T, YANAGIMACHI R, SRIVASTAVA PN, YANAGIMACHI H (1986) Acrosome reaction in human spermatozoa. Fertil Steril 45: 701-707.

NAZ R, AHMED K (1992) Presence of expression products of c-erbB-1 and c-erbB-2/HER2 genes on mammalian sperm cell, and effects of their regulation on fertilization. J Reprod Immunol 21: 223-239.

NAZ R, KAPLAN P (1993) Effects of epidermal growth factor on sperm cell function. J Androl 14: 240-247.

NOLAN JP, HAMMERSTEDT RH (1997) Regulation of membrane stability and the acrosome reaction in mammalian sperm. FASEB J 11: 670-682.

OHZU E, YANAGIMACHI R (1982) Acceleration of acrosome reaction in hamster spermatozoa by lysolecithin. J Exp Zool 224: 259-263.

ONG J, KERR DIB (1990) GABA-receptors in peripheral tissues. Life Sci 46: 1489-1501.

OTOOLE CM, ARNOULT C, DARSZON A, STEINHARDT RA, FLORMAN HM (2000) $\mathrm{Ca}^{2+}$ entry through store-operated channels in mouse sperm is initiated by egg ZP3 and drives the acrosome reaction. Mol Biol Cell 11: 1571-1584.

POTTER LR, YODER AR, FLORA DR, ANTOS LK, DICKEY DM (2009) Natriuretic peptides: their structures, receptors, physiologic functions and therapeutic applications. Handb Exp Pharmacol: 341-366.
PRIMAKOFF P, MYLES DG (2002) Penetration, adhesion, and fusion in mammalian sperm-egg interaction. Science 296: 2183-2185.

RATHI R, COLENBRANDER B, STOUT TAE, BEVERS M, GADELLA BM (2002) Progesterone induces the acrosome reaction in stallion spermatozoa via a protein tyrosine kinase-dependent pathway. Theriogenology 58: 301-311

ROLDAN ER, MURASE T, SHI QX (1994) Exocytosis in spermatozoa in response to progesterone and zona pellucida. Science 266: 1578-1581.

ROTEM R, ZAMIR N, KEYNAN N, BARKAN D, BREITBART H, NAOR Z (1998) Atrial natriuretic peptide induces acrosomal exocytosis of human spermatozoa. Am J Physiol 274: E218-223.

SABEUR K, VO AT, BALL BA (2000) Effects of angiotensin II on the acrosome reaction in equine spermatozoa. J Reprod Fertil 120: 135-142.

SALTIEL AR, KAHN CR (2001) Insulin signalling and the regulation of glucose and lipid metabolism. Nature 414: 799-806.

SHAH C, MODI D, GADKAR S, SACHDEVA G, PURI C (2003) Progesterone receptors on human spermatozoa. Indian J Exp Biol 41: 773-780.

SHI QX, YUAN YY, ROLDAN ER (1997) Gamma-Aminobutyric acid (GABA) induces the acrosome reaction in human spermatozoa. Mol Hum Reprod 3: 677-683.

SHRIVASTAV P, SWANN J, JEREMY JY, THOMPSON C, SHAW RW, DANDONA P (1989) Sperm function and structure and seminal plasma prostanoid concentrations in men with IDDM. Diabetes Care 12: 742-744.

SMITH MS (1980) Role of prolactin in mammalian reproduction. Int Rev Physiol 22: 249-276.

SOLAKIDI S, PSARRA AM, NIKOLAROPOULOS S, SEKERIS CE (2005) Estrogen receptors $\alpha$ and $\beta$ (ER $\alpha$ and ER $\beta$ ) and androgen receptor (AR) in human sperm: localization of ER $\beta$ and AR in mitochondria of the midpiece. Hum Reprod 20: 3481-3487.

STOVALL DW, SHABANOWITZ RB (1991) The effects of prolactin on human sperm capacitation and acrosome reaction. Fertil Steril 56: 960-966.

SUELDO CE, OEHNINGER S, SUBIAS E (1993) Effect of progesterone on human spermatozoa by a fraction of human follicular fluid. Gamete Res 14: 10 .

TAKANO H, YANAGIMACHI R, URCH UA (1993) Evidence that acrosin activity is important for the development of fusibility of mammalian spermatozoa with the oolemma: inhibitor studies using the golden hamster. Zygote 1: 79-91.

TESARIK J, MENDOZA C (1993) Insights into the functions of a sperm surface progesterone evidence of ligand-induced receptor agregation and the proteolysis. Exp Cell Res 205: 111-117.

TESARIK J, MOOS J, MENDOZA C (1993) Stimulation of protein tyrosine phosphorylation by a progesterone receptor on the cell surface of human sperm. Endocrinology 133: 328-335.

TSUTSUMI O, KURACHI H, OKA T (1986) A physiological role of epidermal growth factor in male reproductive function. Science 233: 975-977.

VIGIL P, VIAL CORREA JD, HERRERA E, BARROS C (1985) Observaciones ultraestructurales de espermatozoides de un paciente astenoespérmico. Rev Chil Obst Ginecol 50: 62-66.

VIGIL P (1987) Características morfofuncionales del espermatozoide de mamífero durante la fusión gamética. PhD thesis. Santiago: Facultad de Ciencias Biológicas, Pontificia Universidad Católica de Chile. pp: 1-128.

VIGIL P (1989) Gamete membrane fusion in hamster spermatozoa with reacted equatorial segment. Gamete Res 23: 203-213.

VIGIL P, PÉREZ A, NEIRA J, MORALES P (1991) Post-partum cervical mucus: biological and rheological properties. Hum Reprod 6: 457-479

VIGIL P, RUBIO V, PRADO S, SOCÍAS T, SALGADO AM, MORALES P (1994) Migration of human sperm through the Fallopian tube in vitro. In: RODRÍGUEZ-ARMAS O, BAUMGARTNER W, BURGOS-BRICEÑO L (eds) Fertility and sterility progress in research and practice: The proceedings of the XIV World Congress on Fertility and Sterility. Caracas: Parthenon Publ Group. pp: 19-30.

VIGIL P, RIQUELME R, MORALES P (1995) Sperm binding to the human zona pellucida after migration through human cervical mucus. Int $\mathrm{J}$ Androl 18: 7-11.

VIGIL P, TORO A, GODOY A (2008) Physiological action of oestradiol on the acrosome reaction in human spermatozoa. Andrologia 40: 146-151.

VIGIL P, CORTÉS ME, ZÚÑIGA A, RIQUELME J, CERIC F (2009a) Scanning electron and light microscopy study of the cervical mucus in women with polycystic ovary syndrome. J Electron Microsc 58: 21-27.

VIGIL P, ORELLANA RF, BARRIENTOS V, GODOY A, DELRÍO MJ (2009b) Effects of GABA, progesterone and estradiol on human acrosome reaction. J Androl 30(Suppl S): 82-83.

VIGIL P, ORELLANA R, GODOY A, BARRIENTOS V, DELRÍO MJ (2009c) Effects of gamma-amino butyric acid, progesterone and oestradiol on human spermatozoa acrosome reaction. In: BALLESCÀ 
LAGARDA JL, OLIVA VIRGILI R (eds) Papers contributed to the 9th International Congress of Andrology. Barcelona: Medimond International Proceedings. pp: 107-111.

VINSON GP, PUDDEFOOT JR, HO M, BARKER S, MEHTA J, SARIDOGAN E, DJAHANBAKHCH O (1995) Type 1 angiotensin II receptors in rat and human sperm. J Endocrinol 144: 369-378.

VISCONTI PE, MUSCHIETTI JP, FLAWIA MM, TEZON JG (1990) Bicarbonate dependence of cAMP accumulation induced by phorbol esters in hamster spermatozoa. Biochim Biophys Acta 1054: 231-236.

VISCONTI PE, MOORE GD, BAILEY JL, LECLERC P, CONNORS SA, PAN D, OLDS-CLARKE P, KOPF GS (1995) Capacitation of mouse spermatozoa. II. Protein tyrosine phosphorylation and capacitation are regulated by a cAMP-dependent pathway. Development 121: 1139-1150.

VISCONTI PE, KOPF GS (1998) Regulation of protein phosphorylation during sperm capacitation. Biol Reprod 59: 1-6.

VON KÖLLIKER RA (1841) Beiträge zur Kenntniss der Geschlechtsverhältnisse und der Samenflüssigkeit wirbelloser Thiere nebst einem Versuch über das Wesen und die Bedeutung der sogenannten Samenthiere. Berlin: W. Logier. pp: 1-88.

WAY AL, BARBATO GF, KILLIAN GJ (2001) Identification of norepinephrine in bovine oviductal fluid by high performance liquid chromatography. Life Sci 70: 567-576.

WAY AL, KILLIAN GJ (2002) Capacitation and induction of the acrosome reaction in bull spermatozoa with norepinephrine. J Androl 23: 352-357.

WISTROM CA, MEIZEL S (1993) Evidence suggesting involvement of a unique human sperm steroid receptor $/ \mathrm{Cl}^{-}$channel complex in the progesterone-initiated acrosome reaction. Dev Biol 159: 679-690.
YANAGIMACHI R (1970) The movement of golden hamster spermatozoa before and after capacitation. J Reprod Fertil 23:193-196.

YANAGIMACHI R, USUI N (1974) Calcium dependence of the acrosome reaction and activation of guinea pig spermatozoa. Exp Cell Res 89: 161-74.

YANAGIMACHI R (1982) Requirement of extracellular calcium ions for various stages of fertilization and fertilization-related phenomena in the hamster. Gamete Res 5: 323-344.

YANAGIMACHI R (1995) Mammalian fertilization. In: KNOBIL E, NEILL JD (eds) The physiology of reproduction. 2nd ed. New York: Raven Press. pp: 189-317.

YUAN RY, PRIMAKOFF P, MYLES DG (1997) A role for the disintegrin domain of cyritestin, a sperm surface protein belonging to the ADAM family, in mouse sperm-egg plasma membrane adhesion and fusion. J Cell Biol 137: 105-112.

ZAMIR N, BARKAN D, KEYNAN N, NAOR Z, BREITBART H (1995) Atrial natriuretic peptide induces acrosomal exocytosis in bovine spermatozoa. Am J Physiol 269: E216-221.

ZHANG M, TANG H, SHEN G, ZHOU B, WU Z, PENG Z, ZHANG J, YAN J XIA G (2005) Atrial natriuretic peptide induces an acrosome reaction in giant panda spermatozoa and enhances their penetration of salt-stored porcine oocytes. Theriogenology 64: 1297-1308.

ZHANG M, HONG H, ZHOU B, JIN S, WANG C, FU M, WANG S, XIA G (2006) The expression of atrial natriuretic peptide in the oviduct and its functions in pig spermatozoa. J Endocrinol 189: 493-507.

ZHAO L, BURKIN HR, SHI X, LI L, REIM K, MILLER DJ (2007) Complexin $\mathrm{I}$ is required for mammalian sperm acrosomal exocytosis. Dev Biol 309: 236-244. 
